\title{
[W.P.S.J., の紹介〕
}

\author{
W.P.S.J., Vol. 48, No. 2（1992）〔目次紹介〕
}

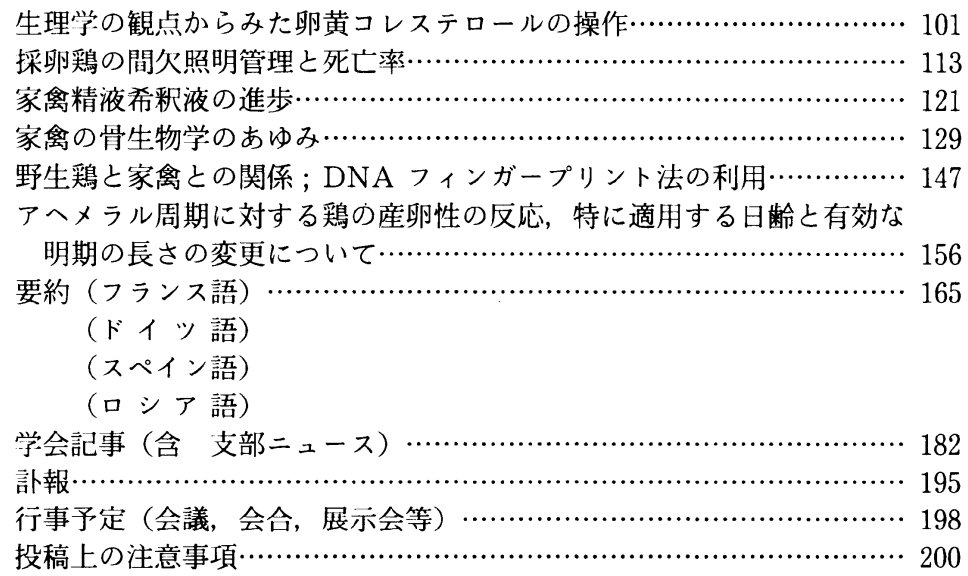

\section{採卵鶏の間欠照明管理と死亡率}

P.D. Lewis et al. : W.P.S.J., 48 (2), 113 (1992) 採卵鷄に対する間欠照明は，飼料や電力の節減，卵重 や卵款質の改良によって, 資源を保護し産卵性を向上さ せる。

1987 年に英国政府が発行した家禽福祉に関するリー フレットには「24 時間ごとに暗期を設けるという規定 が設定されるべきであること，明期が自然光でない場合 は最低 8 時間の照明を行うべきであること」が書かれて いる。これによれば，照明方法に関して具体的に示され てはいないものの，多くの間欠照明法が不幸にも禁止さ れることになる。

これまで間欠照明に関して，産卵性，飼料の利用性と いった生産面での利点を明らかにした報告は数多い。こ こでは死亡率や福祉の面から検討した報告をレビューし た。

\section{間欠照明の分類}

間欠照明は 24 時間周期に複数回の明暗周期を設ける 管理法で，方法によってその効果む異なり，また福祉の 面で重要な鷄の行動に影響する場合もある。間欠照明に

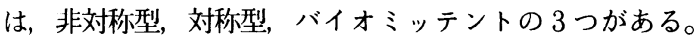
非対称型は 24 時間内に周期の異なる $2 つ$ つ明暗周期を 持つもので, 昼と夜の認識が鶏にある。対称型は短い明 暗周期を繰り返すもので，暗期が短いため夜の認識がな い。バイオミッテントは明期の 1 時間をさらに 15 分明,
45 分暗というように細かく管理する方法である。

\section{死亡率}

通常照明と間欠照明の比較試験で死亡率について調査 した。各間欠照明法とも平均死亡率は通常照明より低か った。有意差のあるあのは 1 例だけだが，全体では間久 照明の方が有意に低く，特にバイオミッテントがよかっ た。間欠照明の全明期時間が 10 時間以下では，間欠照 明の方が死亡率が低かったが，通常之同じ 16 時間の場 合は間欠照明の方が高かった。したがって間欠照明では 全明期時間が少ないことが生存率の改善につながると考 えられる。その原因は不明だが, 間欠照明では脂肪肝破 裂による死亡が少なかったことの報告もある。

\section{目の伤害}

明暗周期のない連続明期や連続暗期では，鵎の目の異 常が報告されている。したがって全明期時間の短い間欠 照明では連続暗期と，また対称型では連続明期の鶏と同 じ異常がおきる可能性がある。しかし非対称型では目の 異常がな゙かったとの報告がある。

\section{鷄の行動}

間欠照明が通常の生活リズムをどの程度阻害するか は，照明法を評価する上で重要である。8 L : $4 \mathrm{D}: 2 \mathrm{~L}$ ：

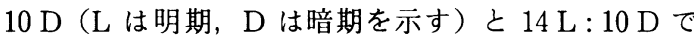
は 1 日の行動にほとんど差はないが，間欠照明の中間暗 期に鶏がおとなしくなる。バイオミッテントの 45 分の 中間暗期にも同じことがみられる。したがって間欠照明 の方が休息時間が長くなる。こうした点から間欠照明は 
鶏本来の周期性を保ちながらも，その行動を制限してい ると考えられる。バイオミッテントを含む非対称型では, 鶏は長いうの暗期を夜とし，残りを昼と認識する。また 夜明けと日没時刻が通常照明と同じ場合は，産卵数や卵 重が同じくらいで，排卵周期の制御に関係する内分泌系 の周期が中間暗期に影響されないことを示している。松 果体のメラトニン産生は夜に最大となり，昼に最小にな る。非対称型の中間暗期の向清中のメラトニン濃度は通 常照明と同じで，鶏は昼と認識して反応していることを 六している。しかし対称型では放卵間隔が長くなったり， 放卵時刻が同調しなくなったりして，鶏の内分泌活性の 周期性が変化する。

\section{光に対する心理的要求}

鶏が光に対して心理的要求があるとすれば，SAVORY \& DUNCAN の報告から 1 日 5 時間以下であろう。

\section{肥 満}

LEWIS らは $2 \mathrm{~L}: 4 \mathrm{D}: 8 \mathrm{~L}: 10 \mathrm{D}$ で 1 年閣飼育した 鶏は $17 \mathrm{~L}: 7 \mathrm{D}$ で飼育したものより，脂肪が少なく体重 が小さいことを報告した。このことは間灭照明によって 産卵鶏の健康を促進することが可能であること，および 脂棜肝や腹膜炎の発症を抑えられるかもしれないことを 示唆している。

\section{暑熱ストレスと悪癖}

閒欠照明は暑熱ストレスの緩和にも効果的で，ブロイ ラーの試験で環境温度を高くしても，14 時間の昼に 4 時閒の暗期を入れると直腸温の上昇が抑えられたとの報 告がある。アメリカの養鵎家もバイオミッテントの鶏は 静かで尻つつきも少なく，暑熱にも強い之言っているな ど，間火照明の方が悪癖の発生が少なく鶏の福祉には良 いと考えられる。

\section{考 察}

明期が 10 時間以下の間火照明は，死亡率の低下や肥 満や覀癖の防止，暑熱耐性の向上によって採卵鶏に快適 な環境を与えている。1日 8 時間以下の照明が鶏の福祉 に悪影響を与えるであろうとするイギリスの福祉条項は 根拠が薄く，むしろ間欠照明で全明期時間を短くすると 死亡乘が低くなる。採卵鶏には飼料が摂取できて，管理 人が見问りできる照明時間で十分之言えるかも知れない。

（菲澤圭一郎・畜試）

\section{アヘメラル明暗周期に対する鷄の産卵性の反応，特に 適用する日齢と有効な明期の長さの変更について}

M.M. Shanawany : W.P.S.J., 48 (2), 156 (1992)

最近，産卵鷂に対するアヘメラル明暗周期の応用につ いての関心が高まってきているが，奏際に適用する場合 にはその性質をよく理解する必要がある。明暗周期の長
さの変更に対する反応には主として 2 つの要因が関係し ている。それは，明暗周期の長さを変更する際の鶏の 日歯之, 変更前後の明喑周期の “有効な明期の長さ” (effective photoperiod) の差である。本稿では,これ までに報告されたデー夕をもとに，これらの問題につい ての分析を行った。

\section{理論的背景}

一般に，24 時䦙より短い明暗周期下においては鵎の 産卵率は低下し，卵重は産卵率の低下に伴い重くなる傾 向を示す。しかし厳密には，この反応は明暗周期の長さ を変更する時の鶏の日齢と密接に関係しており，常に同 じ反応を示すとは限らない。鶏の産卵は通常クラッチを 形成するが，産卵率の高低により，クラッチの長さ，ク ラッチ内平均放卵間隔, クラッチ間平均放卵間隔が変化 する。このクラッチが形成されるのは, 鶏の放卵パター ンが 2 つ非同調性の機構, すなわち卵胞の成熟周期 （24〜27 時間周期）之, 明暗周期と同調する性質のある 生体リズム（自由継続リズムは 23〜26 時間周期）とに より構成されているためである。また, 鶏の産卵は 1 日 のうちの 8〜10 時間の限られた時間帯にのみ行われるが, これは下垂体からの LH（黄体形成ホルモン）の放出可 能な時間帯であるオープンピリオドが同様な時闒帯に限 られているためである。

\section{明暗周期を変更する際の鶏の日齢の影響} -24 時間より長い明暗周期の場合一

例として, 卵胞の成熟周期が 25 時間の鶏の産卵率に ついて考えてみる。この鷄は 24 時間明暗周期下では, クラッチ内平均放卵間隔は 25 時間, クラッチ間平均放 卵間隔は 38 時間，したがって全体の平均放卵閪隔は 26.4 時間となり，産卵率は $91 \%$ となる。この鶏を 28 時間明暗周期下に移すと, クラッチ内平均放卵閶隔は明 暗周期の影響をうけて 28 時間となるが，休産日がなく なって全体の平均放卵閒隔は 28 時閂となり, 産卵率 （24 時間周期に換算）は $85 \%$ となる。しかし，怣際に は卵胞の成熟周期は常に一定ではなく，鶏の日㱓によっ て影響され，日齢が進むにつれ長くなる性質を示す。し たがって，24 時間より長い明暗周期に対する産卵率の 反応は鶏の日齢によって異なり，卵胞の成熟周期が短い 日齢では産卵率は低下し，逆に卵胞の成熟周期が長くな った日龄では産卵率は上昇する傾向を示すことになる。 卵重は常に重くなる傾向を示すが, 産卵率の低下の程度 が大きい場合には卵重の増加の程度も大きくなる。

\section{明暗周期を変更する際の鶏の日齢の影䡴} -24 時間より短い明暗周期の場合一

通常の 24 時閏明暗周期下では 24 時間に 1 個の産卵が 限界となるが，産卵ピークの日齢にあたる集寺では卵胞 
の成熟周期が 23 時間を示す個体も認められる。このよ うな鶏では 23 時閌明暗周期を適用することにより 24 時 間明暗周期下より産卵率を向上させることができる。し かし, この反応も舀の日齢が進み, 卵胞の成熟周期が徐々 に長くなるにつれて減少し，産卵のピークを過ぎた鶏で は産卵率は逆に低下するようになり，日㱓が進むにつれ てその程度はさらに大きくなる。卵重は産卵率の低下に 伴い重くなる傾向を示す。

\section{有効な明期の長さの変化の影響}

有効な明期の長さとは $\mathrm{p}+\mathrm{c}-\mathrm{b}$ によって战される值 で, $\mathrm{p}$ は実際の明期の長さ, $\mathrm{c}$ は明暗周期の長さ， b は 鵎の内因性の生体リズムの周期をそれぞれ表す。これを 用いると, 明暗周期の長さが異なっても光の刺激効果の
強弱を比較することができる。例えば， b の值を 24 時 間と仮定すると，有効な明期の長さは $12 \mathrm{~L}: 12 \mathrm{D}$ では 12 時間, $6 \mathrm{~L}: 21 \mathrm{D}$ では 9 時閒, $9 \mathrm{~L}: 18 \mathrm{D}$ では 12 時 閒となり,この場合 $12 \mathrm{~L}: 12 \mathrm{D}$ と $9 \mathrm{~L}: 18 \mathrm{D}$ とは明喑 周期の条件は異なるが, 光の刺激効果としては问じ効果 をもつことになる。これまでのデータをまとめてみると， 明暗周期の変更により有効な明期の長さが長くなった場 合には産卵率の有意な上昇は認められないが，逆に有効 な明期の長さが $2 \sim 3$ 時間短くなった場合には産卵率は 逆に有意な低下を示す傾向が認められた。しかし，有効 な明期の長さを変化させた場合の産卵率の変化について は，今後さらに検討する必要がある。

（内藤 允・畜試） 